УДК 371.2:373:378

DOI:

Геннадій Дмитренко, доктор економічних наук, професор, завідувач кафедри управління персоналом та економіки прачі ПрАТ “ВНЗ "Міжрегіональна Академія управління персоналом"

Едуард Помиткін, доктор психологічних наук, професор, завідувач відділом професіології та психолого-педагогічної діагностики, директор Психологічного консультативно-тренінгового иентру Інституту освіти дорослих НАПН України

Наталія Головач, кандидат педагогічних наук, доцент кафедри управління персоналом та економіки праці ПрАТ “ВНЗ “Міжрегіональна Академія управління персоналом”

\title{
ФОРМУВАННЯ ЗДАТНИХ ДО САМОРЕАЛІЗАЦІЇ ЗДОБУВАЧІВ ОСВІТИ В УМОВАХ ГЛОБАЛІЗОВАНОГО СВІТУ
}

Пропонується нове рішення модернізації національної системи освіти в контексті ідеологіі людиночентризму. Кінцевим результатом освітньої діяльності всіх ступенів освіти визначені параметри особистості, щуо характеризують конкурентоздатність і конкурентоспроможність випускників, здатних самореалізуватися в глобалізованому й інформачійно насиченому світі. Визначено три інновачійні опори конкурентоздатності здобувачів освіти: аналітико-пізнавальна активність особистості; засвоєння на рефлексивному рівні фундаментальних “ядер” знань з кожного предмету; самопізнання параметрів власного “Я”. Запропоновано діджиталізувати систему освіти - впровадити факторно-критеріальні кваліметричні моделі для діагностики якостей і властивостей здобувача освіти, визначення індикаторів їх розвитку.

Ключові слова: самореалізація особистості; факторно-критеріальні кваліметричні моделі; здатних самореалізуватися в глобалізованому й інформаційно насиченому світі; параметри особистості, людиночентризм; інновачійні опори конкурентоздатності; діджиталізація та ін.

Рис. 2. Табл. 1. Лім. 10.

Hennadiy Dmytrenko, Doctor of Sciences(Economics), Professor, Head of the Personnel Management and Labor Economics Department, Interregional Academy of Personnel Management

Eduard Pomytkin, Doctor of Sciences (Psychology), Professor, Head of the Professiology and Psychology and Pedagogical Diagnostics Department, Director of Psychological Consulting Center of the Institute of Adult Education of the National Academy of Pedagogical Sciences of Ukraine

Nataliya Holovach, Ph.D.(Pedagogy), Associate Professor of the Personnel Management and Labor Economics Department, Interregional Academy of Personnel Management

\section{FORMATION OF STUDENTS ABLE TO SELF-REALIZE IN THE CONDITIONS OF THE GLOBALIZED WORLD}

The article focuses on the problem of personality self-realization in Ukrainian society in the conditions of informatization and digitization of the world. Proposed approaches to modernize the national education system in the context of the human-centrism ideology. The article presented the key idea about promoting of personality self-realization during the life within the limits of human morality and national consciousness. The result of the educational activity of all levels of education is determined on a factor-criterion basis of personality parameters. Personality parameters are determining the competitive capability and competitiveness of graduates ability to self-realization in a globalized and information-rich world. Three innovative pillars of the competitiveness of students have been found: an analytical and cognitive activity of the personality; mastering at the reflexive level of fundamental "cores" of knowledge for each subject; self-knowledge of the one's self parameters (professional-personal qualities, character traits, values). It is proposed to digitize the education system - to introduce factor-criterion qualimetric models for the diagnosis of the qualities and properties of the students as indicators of their development. It is suggested to start the interest of the educationalists of interest in self-discovery of their own self from high school. Proposed to carry out it on the next bases: 1) their participation in self-assessment of their own qualities and properties through the selection of criteria and calculation of assessment; 2) visualization of the dynamics of the indices of these measured parameters, which are recorded in the card of personal achievement; 3) obligatory joint discussion of the components of the personal potential of the applicants together with their parents, teachers, psychologists. The results obtained will be recorded in the Personality Achievement Card, which should serve as a documentary basis for discussions and decisions on further training of students.

Keywords: self-realization of personality; factor-based qualimetric models; capable of self-realization in a globalized and information-rich world; personality parameters; human-centrism; innovative pillars of competitive; digitization, etc.

П

остановка проблеми. Об'єктивним фактором світового масштабу (як і факт зміни клімату) є прискорення

глобалізації світу на основі інформатизації та цифровізації суспільств в умовах інтернаціоналізації ринкових відносин. В такій ситуації треба особливу 
увагу приділити формуванню в освіті нового покоління молоді, здатного жити і розвивати цей світ, а не стати його жертвою, що вкрай необхідно особливо зараз Україні.

Якщо звернути увагу на обмежені можливості самореалізації особистості в українському суспільстві, в тому числі і невдалий розвиток системи освіти, то можна побачити суттєві недоліки їі результатів - недостатність у випускників практичних соціальних знань та навичок в умовах інформатизації і цифровізації світу. Ці недоліки обумовлені в першу чергу, відсутністю цілісного усвідомлення сутності реформ, що проводяться сьогодні в освіті під загальним гаслом “Йдемо до Європи!”. Таке усвідомлення може прийти тільки у випадку розуміння людиноцентричного змісту стратегічного розвитку освіти в цивілізованому напрямі з гуманітарною складовою.

Аналіз останніх досліджень і публікацій. На цей час активно проводяться дослідження розвитку освітньої галузі в напрямку поглибленої демократії в контексті філософії людиноцентризму, що може бути одночасно об'єднавчою національною ідеєю розвитку України в глобалізованому світі. Такий напрямок, зокрема, досліджує філософська школа В. Кременя [5; 6], до якої належать наукові доробки: Л. Батліної, В. Ілліна, А. Кузьміча, М. Ліпіна, В. Солодкова та ін. До цієї школи приєдналась група вчених в галузі управління, педагогіки, психології, соціології [3 7; 10], що запропонували нове поняття “еколюдиноцентризм”, щоб уникнути інсинуації стосовно розгляду первинності людини без урахування її гармонічного існування в природному середовищі і збереженню природного потенціалу. Якщо еколюдиноцентризм орієнтувати на сприяння самореалізації особистості впродовж життя, це буде характеризувати його гуманістичну спрямованість, що стає головною умовою удосконалення поглиблення демократії в контексті їі поглиблення. Тобто, в науковій літературі вже простежується той власний шлях модернізації національної системи освіти, який може здійснитися в контексті чіткої реалізації ідеології людиноцентризму. У цьому сенсі необхідним та можливим $є$ розробити власний вектор оновлення системи освіти в Україні.

Метою статті $\epsilon$ висвітлення опорних можливостей освіти формування особистостей, здатних розкрити та реалізувати свій потенціал сьогодні і в майбутньому.

Виклад основного матеріалу дослідження. Загальною ідеологією розвитку світових цивілізованих суспільств є демократія, яка в останні десятиліття все більш демонструє свою недосконалість. Оскільки альтернативи їй немає, треба шукати шляхи ії удосконалення. На початку XXI-го століття філософська школа В.Г. Кременя запропонувала філософію людиноцентризму в якості національної ідеї України [5].

Така національна ідея має двоєдине призначення: визначити генеральну стратегію розвитку держав в цивілізованому напрямі та об'єднати історично роз'єднаних українців задля побудови квітучої України в Європейському Союзі.

Розвиток цієї ідеї в системі освіти так чи інакше пов'язаний $з$ необхідністю формування нового покоління нації, розкриттю (а потім і реалізації) його потенціалу, якому повинна сприяти діяльність закладів всіх ступенів освіти - від дошкільних до вищих. Сьогоднішня стратегія розвитку освіти не здатна наблизитись до реалізації цієї ідеї системних чином.

Тому фундаментальним підтрунтям реалізаціі об'єднуючої людиноцентричної стратегіi розвитку украӥнського суспільства має стати інноваційна система модернізації національноі системи освіти в гуманістичному напрямі. Її інноваційність обумовлюється чіткою орієнтацією діяльності всіх закладів освіти на сприяння самореалізації особистості (через вплив на формування певних іiі параметрів) впродовж життя 3 додержанням єдиної системоутворюючої ідеї (рис. 1).

Кінцевим результатом освітньої діяльності всіх ступенів освіти мають стати виміряні на факторно-критеріальній основі параметри особистості, що характеризують конкурентоздатність і конкурентоспроможність випускників, здатних самореалізуватися в глобалізованому, інформаційно насиченому світі.

Конкурентоздатність особистості, на визначення і формування параметрів якої мають орієнтуватися всі ступені освіти, починаючи 3 закладів дошкільної, базується на трьох опорах, інноваційних за своєю сутністю.

Перша інноваційна опора конкурентоздатності - це аналітико-пізнавальна активність особистості (АПА). У випадку їі розвиненості у людини виникає внутрішня потреба постійно оновлювати і поглиблювати знання та аналізувати інформаційні потоки 3 метою відокремлення головного із множини другорядного. Діагностується вона за допомогою відповідного індексу АПА (починаючи з закладу дошкільної освіти) у кількісному вимірі за допомогою використання факторно-кваліметричних оцінювальних моделей, що стають фундаментом цифровізації освітнього процесу. 


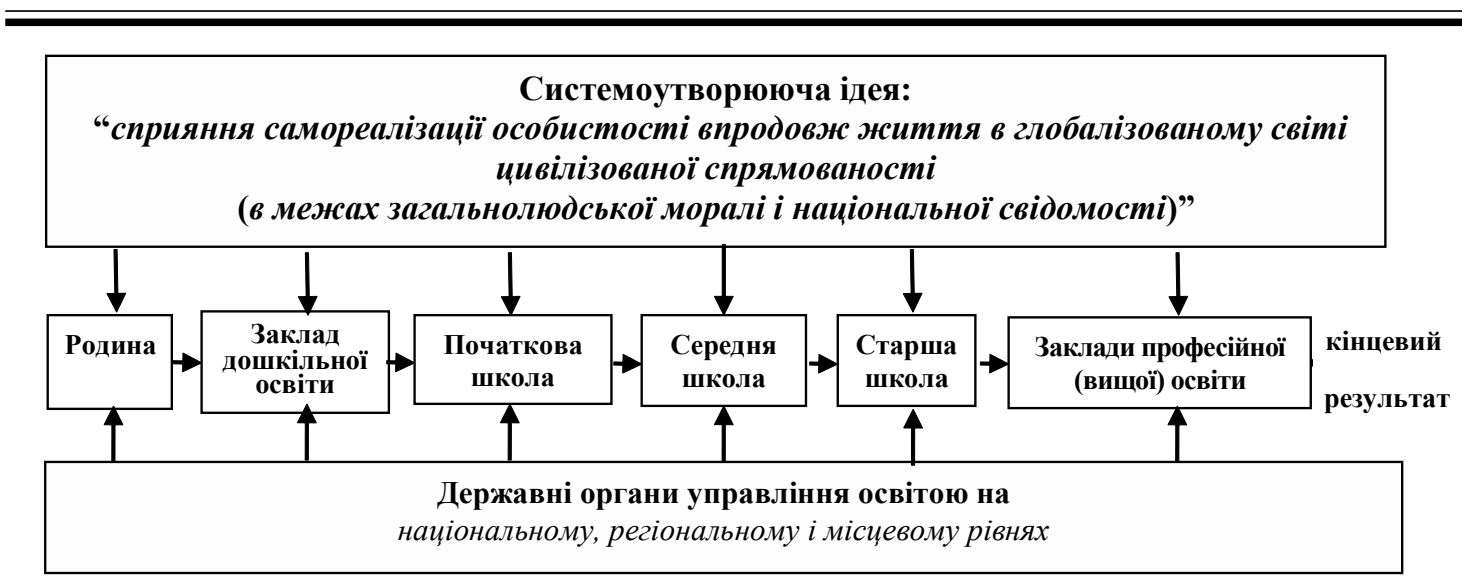

Рис. 1. Об'сднуюча роль системоутворюючої ідеї розвитку людиноцентричної освіти гуманістичної властивості в напряму формування нового покоління нації [2, 79]

Значущість визначення індексу АПА важко переоцінити, маючи на увазі, що саме цей показник, а не виключно тільки оцінки за знання, $€$ дійсним індикатором виконання закладом світи одного $з$ двох своїх головних призначень, а саме: навчити дитину вчитися впродовж життя. Наприклад, якщо здобувач освіти має високий індекс АПА, на який впливають методи розвивального навчання, зокрема проектного, це означає, що його навчили вчитися впродовж життя i засвоювати знання він буде не через запам'ятовування, а через рефлексію, тобто через внутрішне самопізнання і розуміння. Це означає, по-перше - надовго і надійно він здобуває фундаментальні знання, вміння й навички, а подруге - одержані знання стають об'єктом для творчого використання.

Друга інноваційна опора конкурентоздатності - це засвосння здобувачами освіти на рефлексивному рівні (завдяки розвиненій АПА) фундаментальних “ядер" знань $з$ кожного предмету. Мова йде про засвоєння сутності явищ, які не змінюються взагалі (чи змінюються дуже повільно) і базуються на певних законах (не юридичних), закономірностях, тенденціях, принципах та ін. Маючи на увазі, що іншу інформацію про досліджувані явища, у випадку необхідності, здобувачі освіти засвоять самостійно завдяки розвиненій АПА.

Третя інноваційна опора конкурентоздатності - самопізнання здобувачами освіти параметрів власного “Я”, включаючи: професійноособистісні якості (“сродна” прачя - за Г. Сковородою); риси характеру; иінності та $i н$. [10]. Враховуючи вимоги роботодавців, особливе значення для самореалізації в трудовій сфері діяльності грають такі якості, як відповідальність за свої дії (надійність) і толерантність (безконфліктність). Фундаментальною основою цих якостей $є$ рівень моральності з точки зору поваги до інших людей і природи.

Для прищеплення здобувачам освіти інтересу до самопізнання власного "Я" використовується певна технологія, яка базується на залученні до діагностування власних параметрів самих здобувачів. Всі результати діагностування мають заноситися до картки досягнень особистості (КДО) здобувача освіти і обов'язково обговорюватися тріадою експертів: класним керівником, психологом, батьками, здобувачами. Порівняння досягнень здобувачами освіти між собою може викликати у них змагальність як засіб самовдосконалення.

Значущість третьої опори конкурентоздатності важко переоцінити в контексті самореалізації особистості не тільки в трудовій сфері, а також в будь яких інших соціумах. Це дозволяє робити висновки про виконання школою їі другого ключового призначення: навчати молоду людину жити в мультикультурному суспільстві (з вільним володінням міжнародною мовою). Недарма вислів Сократа "пізнай себе” у нашого великого мислителя Г. Сковороди уточнюється так: “нам не добре від того, що ми знаємо багато зайвого, а не знаємо найпотрібнішого: самих себе" [10], є актуальним назавжди.

Конкурентоспроможність базується на конкурентоздатності, яка доповнюється оволодінням здобувачами освіти актуальними знаннями і вміннями згідно потреб ринку праці. Тобто призначенням закладів вищої (професійної) освіти є підготовка конкурентоспроможних випускників. Досягається це шляхом вдосконалення параметрів конкурентоздатності, що формується ще в школі, і виконанням професійних стандартів. Останні чітко відображають вимоги роботодавців стосовно актуальних знань та вмінь, а також професійно- 


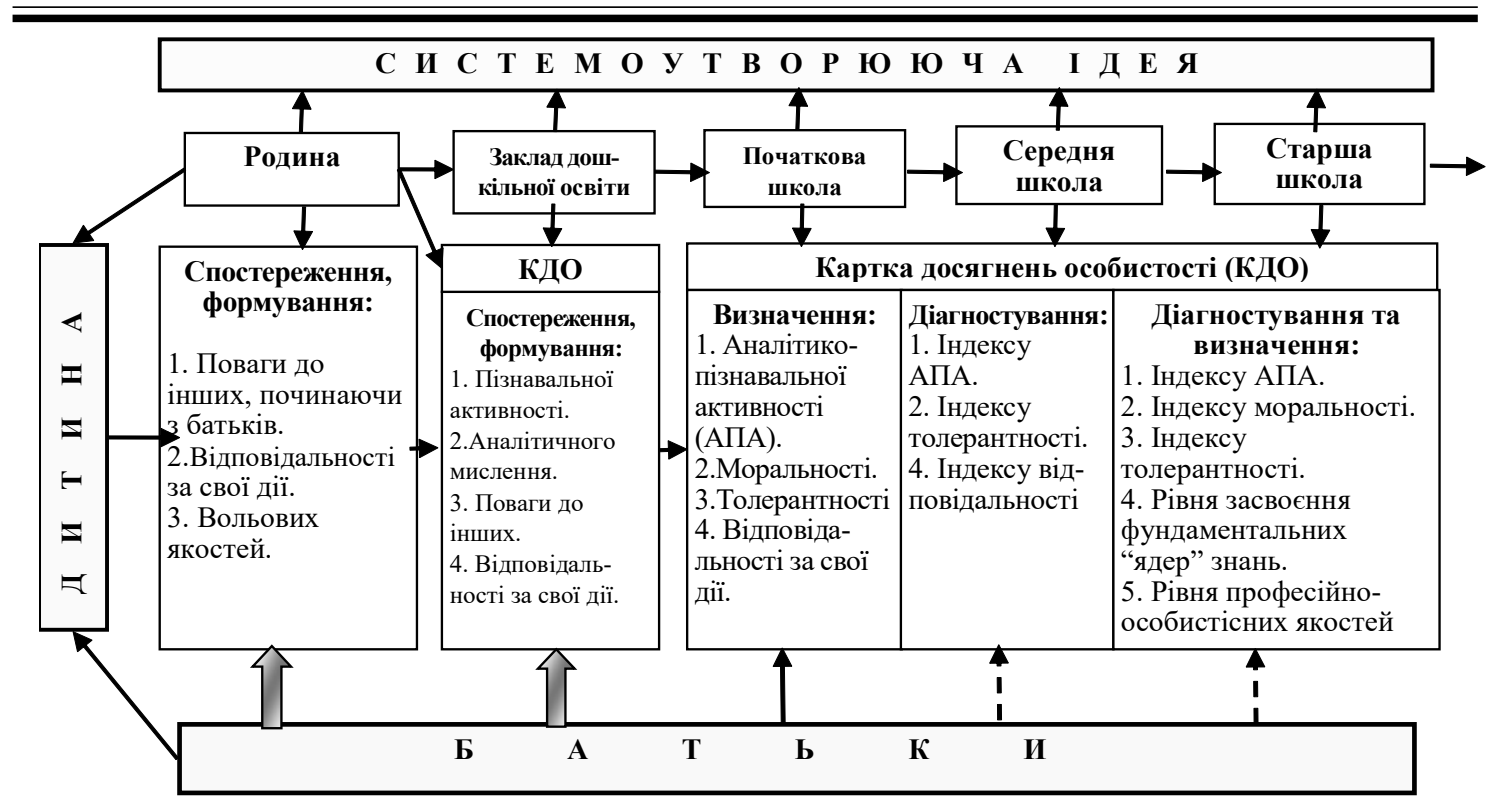

Рис. 2. Системна взасмодія учасників освітнього процесу допрофесійної освіти [2, 119]

особистісних якостей i властивостей до випускника.

Підготовку молодого покоління до професійної самореалізації необхідно починаючи ще з закладів дошкільної освіти. Одним з головних завдань сучасної системи освіти є створення умов та запровадження технології для виявлення і розвитку здібностей особистості, починаючи ще 3 дитинства. Нажаль сучасна система освіти в Україні не зорієнтована на окремого здобувача освіти, не враховує їх особистісний потенціал (здібності, потреби та інтереси, навички, знання, уміння), не встигає оновлюватися та адаптуватися відповідно до динамічних змін у суспільстві.

Безумовно, на даному етапі, для фундаментальної модернізації вітчизняної системи освіти критично не вистачає якісних кадрових ресурсів, фінансових можливостей, досконалої нормативно-правової бази та рівня культури українського суспільства. Але пошук сучасних ефективних механізмів вдосконалення системи освіти в Україні все ж продовжується і здійснюється на основі поглиблення демократії та еколюдиноцентричної ідеології з використанням незвичних та нестандартних засобів.

Мова йде про діджиталізацію системи освіти як розвитку загальної тенденції інформатизації та цифровізації суспільств. Сьогодні це вже $є$ головним трендом розвитку освітніх систем в усіх розвинених країнах світу. Вище вже зазначалося про необхідність використання факторно-критеріальних кваліметричних моделей (ФККМ) для діагностування якостей i властивостей здобувача освіти як індикаторів їх розвитку із занесенням результатів до картки досягнень особистості. Особливість цих моделей полягає, з одного боку, в їх простоті (що цілком реально впровадити їх навіть у самих занедбаних сільських школах), з другого - в їх універсальності і суттєвості глибини, бо в них розкривається сутність будь-якого явища, що розглядається i вимірюється. Ще одна особливість факторнокритеріальних моделей полягає в тому, що вони є “продуктом” відносно нової галузі математики нечіткої математики. Тобто у випадку наявності не зовсім повної вхідної інформації результати на виході завжди будуть однозначними, у індексному вигляді.

Нижче в табл. 1 наведено макет однієї такої базової моделі на прикладі оцінювання толерантності особистості (за таким принципом оцінюються самі різні якості і властивості будьякої особистості) як складової моральності.

Вже в першому стовпчику Таблиці 1 розкривається сутність толерантності в певних факторах. Саме усвідомлення здобувачами освіти цих факторів та їх оцінка 3 різних позицій (самого здобувача, однокласників, вчителів, батьків) стає важелем самопізнання ними цього параметру особистості як частини власного “Я” у кількісному вимірі (в нашому прикладі-055).

Представлена ФККМ оцінки рівня толерантності особистості названа "макетом" тому, що вона може поступово удосконалюватися як 3 точки зору визначення факторів, так i критеріїв їх значущості, а також включення вагомості кожного фактору. Але, принципова 
Таблиця 1.

Макет базової моделі оцінювання рівня (індексу) толерантності здобувача освіти " $\boldsymbol{N}$ " $[3,113]$

\begin{tabular}{|c|c|c|c|c|c|c|}
\hline \multirow{2}{*}{$\begin{array}{c}\text { Фактори } \\
\text { толерантності }\end{array}$} & \multicolumn{5}{|c|}{ Критерії прояву факторів та їх значущість } & \multirow{2}{*}{$\begin{array}{c}\text { Оцінка за } \\
\text { факторами }\end{array}$} \\
\hline & $\begin{array}{c}\text { Завжди } \\
(1,00)\end{array}$ & $\begin{array}{l}\text { Часто } \\
(0,75)\end{array}$ & $\begin{array}{c}\text { Час від часу } \\
(0,50)\end{array}$ & $\begin{array}{l}\text { Інколи } \\
(0,25)\end{array}$ & $\begin{array}{l}\text { Ніколи } \\
(0,00)\end{array}$ & \\
\hline $\begin{array}{l}\text { 1. Прагнення розуміти } \\
\text { співрозмовника }\end{array}$ & & $x$ & & & & 0,75 \\
\hline $\begin{array}{l}\text { 2. Вміння бачити в іншій } \\
\text { людині особистість }\end{array}$ & & $x$ & & & & 0,75 \\
\hline $\begin{array}{l}\text { 3. Поважне ставлення до } \\
\text { протилежних поглядів }\end{array}$ & & & $x$ & & & 0,50 \\
\hline $\begin{array}{l}\text { 4. Поважне ставлення до } \\
\text { різних релігійних } \\
\text { переконань }\end{array}$ & & & & $\times$ & & 0,25 \\
\hline $\begin{array}{l}\text { 5. Вміння бути } \\
\text { некатегоричним під час } \\
\text { спілкування }\end{array}$ & & & $x$ & & & 0,50 \\
\hline Загальна оцінка: & & & & & 5 & $=0$ \\
\hline
\end{tabular}

схема завжди залишається єдиною: фактори висвітлюють сутність явища, критерії визначають їх прояви, а значущість критеріїв (від 1.0 до 0.0) завжди відображає частоту чи яскравість цих проявів. Інша справа, що деякі якості людини проявляються тільки при певних обставинах $\mathrm{i}$ емоційному стані.

Взагалі ж людина буде діяти в залежності від зовнішніх умов (в першу чергу, управлінського

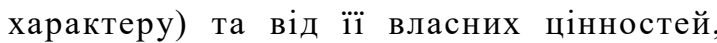
особистісних якостей, в тому числі і моральних.

В цілому неможливо переоцінити важливість таких вимірювань, в першу чергу, з точки зору формування у здобувачів уявлень про рівень своєї моральності, а потім - організації системної мотивації самовдосконалення на основі змагальності, суперництва та зовнішнього їх стимулювання.

Саме иим ми підтверджуємо відому тезу “величайтего ума древности” Аристотеля: “...мы ведь проводим исследование не затем, чтобы знать, что такое добродетель, а чтобы стать добродетельными, иначе от этой науки не было бы никакого проку..." [1].

Не зважаючи на активний супротив бюрократичного механізму деякі позитивні зміни в системі освіти все ж таки відбуваються завдяки різностороннім та широкоформатним дослідженням вітчизняних вчених та активної діяльності окремих просвітницьких та благодійних організацій, наприклад, Благодійного фонду імені Октая Алієва. За підтримки цього фонду група відомих та заслужених вітчизняних вчених в рамках програми курсу “Людина. Родина. Світ" (О. Алієв, Л. Москальова і Е. Помиткін) розробила інноваційну загальноосвітню програму для закладів середньої освіти (з 1 по 12 клас) [8]. Дана програма курсу вже апробована у деяких початкових школах, має позитивні результати та містить стратегічні напрямки розвитку особистості дитини. Крім загальноосвітніх цілей ця програма за головну мету має закладення орієнтації у свідомості дитини на власне щасливе майбутнє у своїй родині, Батьківщині, улюбленій справі.

“Людина. Родина. Світ" - це інтегрований курс, який є першою цеглиною у фундаменті системного формування нового покоління нації гуманістичної спрямованості. Програма акцентує увагу на необхідності розвитку у дітей власного світогляду з цілісним і чітким розумінням світу та самих себе на основі розуміння сенсу своїх дій, самостійного аналітичного мислення, власних переконань, потреб, прагнень, цілеспрямованості [8].

У формуванні здатних до самореалізації здобувачів освіти дуже важливе значення має рівень їх самопізнання власного “ $Я$ ”. На думку авторів [2], таку технологію прищеплення здобувачам освіти інтересу до самопізнання власного “Я” потрібно, починати ще з середньої школи. Проводити це пропонується на засадах: 1) їх участі у самооцінюванні власних якостей і властивостей через вибір критеріїв та розрахунку оцінки; 2) наочному баченні динаміки індексів цих вимірюваних параметрів (особливо моральності), 


\section{ФОРМУВАННЯ ЗДАТНИХ ДО САМОРЕАЛІЗАЦЇ̈ ЗДОБУВАЧІВ ОСВІТИ В УМОВАХ ГЛОБАЛІЗОВАНОГО СВІТУ}

що фіксуються в картці досягнень особистості; $3)$ обов'язковому спільному обговоренні компонентів особистісного потенціалу здобувачів разом $з$ їх батьками, вчителями, психологами, які потім фіксуються в цих картках і стають документальною основою обговорювань та прийняття рішень щодо подальшого навчання та розвитку.

Відтак, головними учасниками процесу прищеплення здобувачам освіти інтересу до самопізнання власного “ $Я$ ” та його розвитку $є$ : самі здобувачі, їх батьки, вчителі (наставники), психологи. Звертаємо увагу на те, що педагоги та психологи компетентні у цьому питанні та за розробленими технологіями готові надавати якісну допомогу здобувачам в умовах освітньовиховного процесу. Натомість, батьки тільки в поодиноких випадках можуть це зробити, i, не завжди якісно та у повній мірі. Системна взаємодія всіх учасників освітнього процесу в контексті реалізації наскрізної системоутворюючої ідеї починається з родини, що необхідно усвідомити самим батькам.

Батьки здобувачів також $є$ суб'єктом управління їх освітою, тому обов'язково $є$ відповідальними з точки зору їх відношення щодо самореалізації своїх дітей в майбутньому житті. Виходячи з цього, виникає необхідність розробити спеціальні просвітницькі програми та методичний інструментарій для батьків щодо їх взаємодії 3 закладами освіти заради щасливого майбутнього їх дітей.

Висновки 3 дослідження і перспективи подальших розвідок у цьому напрямі. В глобалізованому та інформаційно насиченому суспільстві самореалізуватися може та людина, яка здатна, по-перше, постійно оновлювати знання та вміння, аналізувати їх, виокремлювати головне 3 множини другорядного, по-друге, ця людина повинна добре знати сама себе, щоб свідомо пристосовуватися до оточуючих соціумів і будувати свою кар'єру, звертаючи увагу на вислів Конфуція: “Якщо людина визначить свою роботу до душі, то вона не буде працювати у своєму житті ні дня".

У зв'язку 3 цим в процесі модернізації національної системи освіти необхідно концентрувати зусилля всіх учасників освітньої діяльності (від батьків до вчителів, викладачів) на розвитку аналітико-пізнавальної активності здобувачів освіти (на основі засвоєння фундаментальних ядер знань) та сприянні самопізнанню здобувачами власного “Я” за певними параметрами особистості. Мова йде, в першу чергу, про професійно-особистісні якості, толерантність на базі моральності та інші професійно значущі якості.

Bce це можливо зробити за допомогою діджиталізації (переведення інформації в цифрову форму), коли сам здобувач освіти може чітко бачити в індексах результати своїх досягнень в динаміці. Тому подальші дослідження необхідно проводити у напрямі удосконалення методів вимірювання параметрів психологічних та психофізіологічних якостей здобувачів (зокрема, універсальною факторно-критеріальною кваліметрією).

В такому разі, від загальних декларацій щодо руху до Свропи і копіювання певних західних технологій, можна йти до цивілізаційного інформаційно та цифронасиченого суспільства власним шляхом. А саме шляхом поглибленої демократії гуманістичної спрямованості, що обумовлюється додержанням всіх закладів і установ національної системи освіти єдиної системоутворюючої ідеї: “Сприяння самореалізації особистості впродовж життя в глобалізованому світі цивілізаційної спрямованості (в межах загальнолюдської моралі та національної свідомості).

\section{ЛІТЕРАТУРА}

1. Аристотель. Никомахова этика. Т. 1. Соч. в 4-ох томах. Москва: Прогресс. 1973. 340 с.

2. Головач Н. В., Дмитренко Г. А. Системне формування нового покоління нації: гуманістичний контекст: монографія. Київ: ДКС-Центр, 2019.350 с.

3. Дмитренко Г. А. Системне управління: унікальний людиноцентричний вектор підвищення ефективності державно-управлінського механізму в Україні: наукове видання. Київ: ДКС-Центр, 2019. $146 \mathrm{c}$.

4. Кваліметрія в управлінні: гуманістичний контекст: навч. посіб./Г.А.Дмитренко, О. Л.Ануфрієва, Т. І. Бурлаєнко, В. В. Медвідь ; за заг. ред. Г. А. Дмитренка. Київ : Видавництво “Аграрна освіта", 2016. 335 с.

5. Кремень В. Г. Філософія національної ідеї. Людина. Світ. Соціум. Київ : Грамота, 2007.576 с.

6. Кремень В. Г. Філософія людиноцентризму в освітньому просторі. 2-ге вид. Київ: Знання України, 2011. 520 с.

7. Помиткін Е. О. Духовний потенціал особистості: психологічна діагностика, актуалізація та розвиток: посібник. Київ: “Внутрішній світ". 2015. 144 с.

8. Помиткін Е. О. Методичні рекомендації щодо викладання в початковій школі інтегрованого курсу “Людина. Родина. Світ". / Фонд О.Алієва. Київ: “Майстер книг”, 2018. 72 с. 
9. Сисоєва С. О. Освіта як об’єкт дослідження. Шлях освіти. 2011. №2 (60). С. 5-10.

10. Сковорода Г. С. Повне зібрання творів. Т. 12. Київ: Наукова думка, 1973. 576 с.

\section{REFERENCES}

1. Aristotel, (1973). Nikomakhova etika. T. 1. Soch. v 4-okh tomakh [Nikomakhova ethics]. Moscow, 340 p. [in Russian].

2. Holovach, N. V. \& Dmytrenko, H. A. (2019). Systemne formuvannia novoho pokolinnia natsii: humanistychnyi kontekst: monohrafiia [Systematic formation of a new generation the nation: humanistic context: monograph]. Kyiv, 350 p. [in Ukrainian].

3. Dmytrenko, H. A. (2019). Systemne upravlinnia: unikalnyi liudynotsentrychnyi vektor pidvyshchennia efektyvnosti derzhavno-upravlinskoho mekhanizmu v Ukraini: naukove vydannia [System management: a unique human-centric vector of increasing the efficiency of the state-administrative mechanism in Ukraine]. Kyiv, 146 p. [in Ukrainian].

4. Dmytrenko, H. A., Anufriieva, O. L., Burlaienko, T. I. \& Medvid, V. V. (2016). Kvalimetriia v upravlinni: humanistychnyi kontekst : navch. posib. [Kvalimetry in management: the humanistic context]. Kyiv, 335 p. [in Ukrainian].

5. Kremen, V. H. (2007). Filosofiia natsionalnoi idei. Liudyna. Svit. Sotsium [Philosophy of the national idea. Man. World. Socium]. Kyiv, 576 p. [in Ukrainian].

6. Kremen, V. H. (2011). Filosofiia liudynotsentryzmu v osvitnomu prostori [Philosophy of human-centrism in the educational space]. 2-he vyd. Kyiv, 520 p. [in Ukrainian].

7. Pomytkin, E. O. (2015). Dukhovnyi potentsial osobystosti: psykholohichna diahnostyka, aktualizatsiia ta rozvytok: posibnyk [The spiritual potential of the individual: psychological diagnostics, actualization and development: a manual]. Kyiv, 144 p. [in Ukrainian].

8. Pomytkin, E. O. (2018). Metodychni rekomendatsii shchodo vykladannia $v$ pochatkovii shkoli intehrovanoho kursu "Liudyna. Rodyna. Svit." [Methodical recommendations for teaching an integrated course "Man. Family. World."]. Fond Oktaia Aliieva. Kyiv, 72 p. [in Ukrainian].

9. Sysoieva, S. O. (2011). Osvita yak obiekt doslidzhennia. Shliakh osvity [Education as a research object. The path of education]. No.2 (60). pp. 5-10. [in Ukrainian].

10. Skovoroda, H. S. (1973). Povne zibrannia tvoriv [Complete collection of works]. Vol. 1-2. Kyiv, 576 p. [in Ukrainian].

Стаття надійшла до редакції 14.01.2020

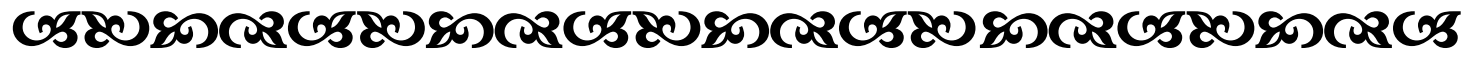

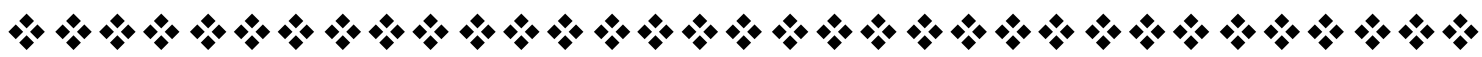

"Ттворіння інтелекту переживають шумну суєту поқолінь $і$ на протязі століть зігрівають світ теплом і світлом".

\section{Альберт Ейнштейн один з найвизначніших бізиків ХХ століття}

“Трирода не знає зупинки в своєму розвитку і знишує усяку бездіяльність".

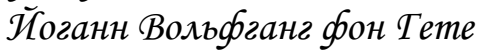
німецький поет, прозаїк, драматург

“Сеқрет майстерності в тому, що секрету немає, є просто-напросто талант". Ірина Вільде

уқрайнська письменниия

“Сильні життєві потрясіння зиіляють від дрібних страхів”.

Оноре де Бальзак франиузький романіст і драматург

\section{G5808न

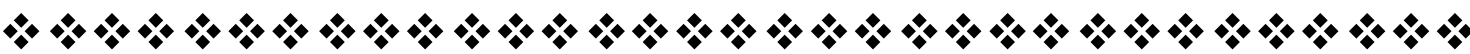

